Acta Haematol 1990;84:I-IV

\title{
Contents, Vol. 84, 1990
}

No. 1

Original Paper

Hb O Padova in a Spanish Family

Martin, G.; Villegas, A.; Calero, F.; del Palacio, S.; Lopez,

J.C.; Lopez, M.; Espinós, D 1

Diisopropylfluorophosphate Binding Proteins (Serine Hydro-

lases) from Normal and Leukemic Hematopoietic Cells

Gonzales, C.R.; Sahai Srivastava, B.I.; Fitzpatrick, J.E. . 5 Inhibition of BFU-E in vitro Growth

and of Burst-Promoting

Activity of T Lymphocytes by Serum of Chronic Uremic

Patients Receiving Hemodialysis

Morra, L.; Ponassi, A.; Moccia, F.; Gurreri, G.; Bessone,

G.; Mela, G.S.; Sacchetti, C 14

Immunoglobulin Gene Rearrangement in the Peripheral Blood

and Bone Marrow of Patients with Lymphomas of the

Mucosa-Associated Lymphoid Tissues

Liang, R.; Chan, V.; Chan, T.K.; Todd, D.; Ho, F 19

Pregnancy-Associated Thrombocytopenia: Definition, Incidence and Natural History

Matthews, J.H.; Benjamin, S.; Gill, D.S.; Smith, N.A. . . 24 Aberrance and Modification of Alpha1 - and Alpha-2-Globin

Gene Expression in Human and Mouse Erythroleukemia

Cells

Mamalaki, A.; Moschonas, N 30

Case Reports

Chronic Lymphocytic Leukemia in a Patient with Systemic

Lupus erythematosus

Lishner, M.; Hawker, G.; Amato, D 38

Erythrocytosis Associated with Renal Artery Thrombosis in a

Patient with Polycystic Kidney Disease on Hemodialysis

Chagnac, A.; Zevin, D.; Weinstein, T.; Gafter, U.; Korzets,

A.; Levi, J 40

Quinidine-Induced Agranulocytosis of Abrupt Onset

Sureda, A.; Hernandez Madrid, A.; Perez Vaquero, M.A.;

Perez de Oteyza, J.; Escribano, L.; Odriozola, J 43

Giant Neutrophils Derived from Tetraploid Leukemic Clone

in an Acute Myeloblastic Leukemia: Cytofluorometric

Study

Fujita, N.; Shimazaki, C; Murakami, S.; Oku, N.; Itoh, K.;

Takeda, N.; Nakanishi, S.; Haruyama, H.; Nishio, A.; Na-

kagawa, M.; Maekawa, T 45

Chronic Granulomatous Disease in an Adult Female with

Granulomatous Cheilitis. Evidence for an X-Linked Pat 
tern of Inheritance with Extreme Lyonization

Dusi, S.; Poli, G.; Berton, G.; Catalano, P.; Fornasa Veller,

C; Peserico, A 49

No. 2

Original Paper

Circulating Megakaryoblasts in Chronic Myeloproliferative

Diseases. An Immunoelectron-Microscopic Study

Matolcsy, A.; Majdic, 0

Detection of Cross-Reacting Idiotypes in Sera of Lymphoma

Patients by Inverse Monoclonal Radioimmunoassay

Ivanovic, V.; Popovié, L.; Kovacina, K.; Dimitrijevié, L.;

Ilic, D.; Pirozkov, A.; Baltic, V

64

Iron Binding to Apotransferrin

Weaver, J.; Pollack, S 68

Hypothyroidism in Patients with Thalassemia Syndromes

Magro, S.; Puzzonia, P.; Consarino, C; Galati, M.C.; Mor-

gione, S.; Porcelli, D.; Grimaldi, S.; Tancrè, D.; Arcuri, V.;

De Santis, V.; Alberti, A 72

Granulocyte Maturation and the Chromosome Deletion 17p-

in Primary Myelodysplastic Syndrome

Pedersen, B.; Kerndrup, G 77

Molecular Characterization and Nonradioactive Detection of Beta-Thalassemia in Malaysia

Fucharoen, S.; Fucharoen, G.; Ata, K.; Aziz, S.; Hashim,

S.; Hassan, K.; Fukumaki, Y 82

In vitro Antibody Synthesis by Peripheral Blood Mononuclear

Cells from Patients with Sickle Cell Disease

Malavé, I.; Escalona, E.; Perdomo, Y.; Pocino, M.; Malavé,

D.; Arends, T 89

Case Reports

Group B Streptococcal Polyarthritis Complicating Hemo

philia B

Hartmann, L.C.; Nauseef, W.M 95

Alternaria Infection in a Patient Receiving Chemotherapy for Lymphoma

Rovira, M.; Marin, P.; Martin-Ortega, E.; Montserrat, E.;

Rozman, C 98

Contents

III

Rhinophyma-Like Cryptococcal Infection as an Early Mani

festation of AIDS in a Hemophilia B Patient

Mares, M.; Sartori, M.T.; Carretta, M.; Bertaggia, A.; Giro-

lami, A101

Short Communication

Essential in vitro Test Before Treatment of Patients with

Intractable Chronic Lymphocytic Leukemia

Schrek, R 104

Correspondence

Hemolytic Anemia Associated with Impaired Erythrocyte

Shape Control

De Angelis, V.; Tommasi, L.G.; Orazi, B.M.; Santarossa, 
L.; Molaro, G 106

Folate Deficient Neuropathy

Parry, T.E 108

Chronic Neutrophilic Leukemia with Dysplastic Features

Cervantes, F.; Rozman, M.; Vives-Corrons, J.-Ll.; Roz-

man, C 109

High-Dose Intravenous Methylprednisolone for Thrombotic

Thrombocytopenic Purpura

Özsoylu, S 110

Immunologic Mechanism in Sulphasalazine-Induced Agranu-

locytosis

Victorino, R.M.M.; Maria, V.A.J.; de Deus, J

Announcement 112

No. 3

Original Paper

High Incidence of Cardiomyopathy in Beta-Thalassaemia Patients Receiving Regular Transfusion and Iron Chelation: Reversal by Intensified Chelation

Aldouri, M.A.; Wonke, B.; Hoffbrand, A.V.; Flynn, D.M.;

Ward, S.E.; Agnew, J.E.; Hilson, A.J.W 113

Decreased Lymphocyte Subsets and K-Cell Activity in Iron

Deficiency Anemia

Santos, P.C.; Falcão, R.P 118

Efficacy of Danazol in Hematologic Disorders

Ahn, Y.S 122

Hyperammonemia in Multiple Myeloma

Matsuzaki, H.; Uchiba, M.; Yoshimura, K.; Yoshida, M.;

Akahoshi, Y.; Okazaki, K.; Takatsuki, K 130

Compound Heterozygosity for a Mild $\aleph_{+}$and a Rare $\aleph^{\circ}$-Thal-assemia Allele

Codrington, J.; Anijs, J.; Wisse, J.H.; Codrington, F.A.; Li, H.; Kutlar, F.; Ramachandran, M.;

Huisman, T.H.J. ... 135

Enhancement of the Fibrinolytic Activity in Plasma by Oral Administration of Nattokinase Sumi, H.; Hamada, H.; Nakanishi, K.; Hiratani, H. ... 139

Impact of Advanced Age on the Management of Acute Non-lymphocytic Leukemia: A Study of 103 Patients Orlandi, E.; Lazzarino, M.; Morra, E.; Castagnola, C; Ales-sandrino, E.P.;

Bernasconi, P.; Bonfichi, M.; Bernasconi, C. 144

Case Reports

Role of D Dimer in Patients with Elevated Fibrinogen Degradation Products in Serum: Further

Study in Chronic My-elogenous Leukemia

Saito, M.; Asakura, H.; Jokaij, H.; Uotanzi, C; Kuma-bashiri, I.; Yoshida, T.; Hashizume, K.;

Matsuda, T. ... 149

Establishment and Characterization of Acute B-Cell Lymphocytic Leukemia Cell Line Showing

$(8 ; 14)$ and $(14 ; 18)$ Chromosome Translocation

Matsuzaki, H.; Hata, H.; Asou, N.; Suzushima, H.; Aka

hoshi, Y.; Yoshida, M.; Nagakura, S.; Ishii, T.; Sanada, I.;

Takatsuki, K 156

Heterozygous Protein-S Deficiency: A Study of a Large Kindred

Girolami, A.; Simioni, P.; Lazzaro, A.R.; Pontara, E.;

Ruzza, G 162

No. 4

Original Paper 
Human Urinary Erythropoietin: Preparation with High Potency

Matsushita, J.; Kawakita, M.; Shibuya, K.; Koishihara, Y.;

Sakaguchi, M.; Takatsuki, A 169

Circulating Myeloid Progenitor Cell Kinetics during Hematologic Recovery from Chemotherapy and Subsequent Re-combinant Human Granulocyte-Macrophage Colony-Stimulating Factor

Administration Ventura, G.J.; Reading, C.L.; Hester, J.P.; Vadhan-Raj, S. 175

Hepatitis B in Household Contacts with Children with Beta-Thalassemia

Papanastasiou, D.A.; Spiliopoulou, I.Th.; Papageorgiou,

O.G.; Beratis, N.G 182

Antinuclear Antibodies in Sickle Cell Disease

Baethge, B.A.; Bordelon, T.R.; Mills, G.M.; Bowen, L.M.;

Wolf, R.E.; Bairnsfather, L 186

Case Reports

A Patient with Transient Autoanti-Jka

Wernli, R.Y.; Strauss, R.G.; Cordle, D.G 190

Circulating Inhibitor Associated with Viral Infection

Keshava Prasad, H.S.; Bradshaw, A.E 193

Pure Red-Cell Aplasia of Long Duration after Major ABO-

Incompatible Bone Marrow Transplantation

Volin, L; Ruutu, T 195

Aplastic Anemia Associated with Ataxia and Chromosome

Translocation $(1 ; 20)$

Nagata, M.; Hara, T.; Sakamoto, K.; Ueda, K

Intramedullary Neutrophil Phagocytosis by Histiocytes in Autoimmune Neutropenia of Infancy

Shimizu, H.; Sawada, K.; Katano, N.; Sasaki, K.; Kawai,

S.; Fujimoto, T 201

Hairy Cell Leukemia Involving an Inguinal Hernial Sac

Melaragno, M.J.; Theil, K.S.; Marsh, W.L.; Sedmak, D.D.;

Bouroncle, B.A 204

IV

Contents

Sweet's Syndrome during the Chronic Phase of Chronic My-

eloid Leukaemia

Bello Lopez, J.L.; Fonseca, E.; Manso, F 207

Thrombotic Thrombocytopenic Purpura Associated with Transient Chromosomal Aberrations:

Successful Treatment with Plasma Exchange

Itoh, Y.; Taniguchi, T.; Takeyama, N.; Kuriki, H.; Ta-

naka, T209

16;21 Translocation in Acute Nonlymphocytic Leukemia with

Abnormal Eosinophils: A Unique Subtype

Sadamori, N.; Yao, E.; Tagawa, M.; Nakamura, H.; Sasa-

gawa, I.; Itoyama, T.; Tokunage, S.; Ichimaru, M.; Naka

mura, I.; Kamei, T.; Yokoyama, Y 212

Author Index 217

Subject Index 219

S. Karger - Medical and Scientific Publishers

Basel · München · Paris · London · New York · New Delhi · Bangkok · Singapore · Tokyo ·

Sydney

Drug Dosage 
The authors and the publisher have exerted every effort to ensure that drug selection and dosage set forth in this text are in accord with current recommendations and practice at the time of publication. However, in view of ongoing research, changes in government regulations, and the constant flow of information relating to drug therapy and drug reactions, the reader is urged to check the package insert for each drug for any change in indications and dosage and for added warnings and precautions. This is particularly important when the recommended agent is a new and/or infrequently employed drug.

All rights reserved.

No part of this publication may be translated into other languages, reproduced or utilized in any form or by any means, electronic or mechanical, including photocopying, recording,

microcopying, or by any information storage and retrieval system, without permission in writing from the publisher or, in the case of photocopying, direct payment of a specified fee to the Copyright Clearance Center (see 'Information for Readers and Subscribers').

(C) Copyright 1990 by S. Karger AG, P.O. Box, CH- 4009 Basel (Switzerland) Printed in Switzerland by Buchdruckerei Basler Zeitung, Basel 